\title{
MANAJEMEN PIMPINAN PONDOK PESANTREN DALAM MENGEMBANGKAN KEGIATAN EKTRAKURIKULER PADA PESANTREN THAWALIB GUNUNG PADANG PANJANG
}

\author{
Rahmawati \\ SDN 08 Baringin Lima Kaum Batusangkar, Sumatera Barat \\ e-mail: rahmawatiliterasi@gmail.com
}

socen

\begin{abstract}
The back.ground of this research from Extracurricular Activities in schools is a forum for the development of students' talents and interests as well as the development of the potential and personality and character of students. This activity will have a positive impact on student behavior and achievement if managed properly and appropriately. The purpose of this study is to see how the management of the Gunung Padang Panjang boarding school in managing extracurricular activities can run well even with achievements at the district, province and level national. This type of research is a qualitative research with a case study design. In collecting data, researchers conducted observations, interviews directly and in-depth and documentary studies. Sources of data in this study were Islamic Boarding School Leaders, vice principals in student fields, teachers, students and the community. The results showed that the management of Islamic boarding school leaders in developing extracurricular activities at the Gunung Padang Panjang Thawalib Islamic Boarding School was applying management principles in general that met the criteria of planning, organizing, controlling and controlling as well as evaluating or commonly called $P O A C$.
\end{abstract}

Keywords: Manajemen, Pimpinan Pondok Pesantren, Kegiatan Ektrakurikuler

\section{PENDAHULUAN}

Pendidikan, kurikulum dan pengajaran merupakan tiga aspek yang saling berhubungan. Pendidikan bertujuan untuk menggali potensi-potensi tersebut menjadi aktual. Pendidikan merupakan alat untuk memberikan rangsangan agar potensipotensi manusia dapat berkembang optimal. Dalam hal ini pendidikan sering diartikan sebagai upaya manusia untuk memanusiakan manusia.

Kurikulum 2013 kegiatan ekstrakurikuler dibedakan menjadi kegiatan ekstrakurikuler wajib dan kegiatan ekstrakurikuler pilihan. Pada lampiran III Permendikbut No 81A (2013 h. 21) kegiatan ekstrakurikuler wajib merupakan kegiatan ekstrakurikuler yang wajib diikuti oleh seluruh siswa, kecuali siswa yang berkebutuhan khusus yang tidak memungkinkan untuk ikut dalam kegiatan ekstrakurikuler. Pada Kurikulum 2013, telah ditetapkan Pramuka sebagai kegiatan ekstrakurikuler wajib dari Sekolah Dasar (SD) sederajat sampai dengan Sekolah Menengah Atas (SMA) sederajat. Selanjutnya, kegiatan ekstrakurikuler pilihan, antara lain OSIS, UKS, dan PMR. Kegiatan 
ekstrakurikuler pilihan dibentuk berdasarkan kelompok-kelompok kegiatan ekstrakurikuler pilihan yang ada, dan biasanya kegiatan tersebut merupakan pengembangan aplikatif dari suatu mata pelajaran, misal ekstrakurikuler Seni Beladiri merupakan aplikasi dari mata pelajaran Pendidikan Jasmani dan Kesehatan dan sebagainya.

Salah satu upaya sekolah untuk memperhatikan berbagai potensi yang ada pada diri peserta didik agar dapat dikembangkan dengan maksimal adalah melalui kegiatan ekstrakurikuler yang diharapkan sebagai wadah bagi peserta didik untuk mengembangkan minat dan bakatnya menjadi suatu keterampilan yang mendukung kualitas kemampuan dirinya sebagai generasi muda yang baik sehingga kelak memiliki prestasi akademik yang tinggi dan didukung oleh potensi nonakademik yang salah satunya berupa life skills (kecakapan hidup) yang terlatih dengan baik. Seperti yang tersebut dalam tujuan pelaksanaan ekstrakurikuler di sekolah menurut Direktorat Pendidikan Menengah Kejuruan dalam B. Suryosubroto (2009: 287) sebagai berikut:

1. Kegiatan ekstrakurikuler harus meningkatkan kemampuan siswa beraspek kognitif, afektif dan psikomotor.

2. Mengembangkan bakat dan minat siswa dalam upaya pembinaan pribadi menuju pembinaan manusia seutuhnya yang positif.

3. Dapat mengetahui, mengenal serta membedakan antara hubungan satu pelajaran dengan pelajaran lainnya.

Kegiatan ekstrakurikuler adalah program pendidikan yang alokasi waktunya tidak ditetapkan dalam kurikulum. Kegiatan ekstra-kurikuler merupakan perangkat operasional (supplement dan complements) kurikulum, yang perlu disusun dan dituangkan dalam rencana kerja tahunan/kalender pendidikan satuan pendidikan. Kegiatan ekstrakurikuler menjembatani kebutuhan perkembangan peserta didik yang berbeda; seperti perbedaan rasa akan nilai moral dan sikap, kemampuan, dan kreativitas. Melalui partisipasinya dalam kegiatan ekstrakurikuler peserta didik dapat belajar dan mengembangkan kemampuan berkomunikasi, bekerja sama dengan orang lain, serta menemukan dan mengembangkan potensinya. Kegiatan ekstrakurikuler juga memberikan manfaat sosial yang besar.

Syatibi (2013: 179) dalam bukunya Pengembangan \& Inovasi Kurikulum, menjelaskan; adapun langkah-langkah yang perlu diambil dalam merancanakan program ekstrakurikuler secara garis besar antara lain: 1. Menganalisis kebutuhan atau keperluan (need analysis) peserta didik dalam proses pendidikan yang berpangkal dari hasil kegiatan intra dan ekstrakurikuler, apresiasi masyarakat sekitar, rata-rata usia peserta didik, kegemaran, dan keperluasan pesantren;

2. Merumuskan dan mengajukan saranasarana yang diperlukan, di mana peserta didik dapat diikutsertakan secara aktif disertai dengan bimbingan guru;

3. Menghaluskan rumusan dan sasaransasaran dengan menambah dan mengurangi atau bahkan memperbaiki kegiatan-kegiatan tersebut, untuk kemudian menetapkan kegiatan-kegiatan yang akan melengkapi program ekstrakurikuler; 
4. Penanaman nilai-nilai karakter bangsa dalam proses kegiatan ekstrakurikuler melalui pembiasaan (habituasi) yang dilaksanakan mulai dari perencanaan, pelaksanaan dan penilaian.

5. Penilaian yang dilakukan pada waktu berlangsungnya kegiatan dan setelah pelaksanaan kegiatan.

Pondok Pesantren Thawalib Gunung Padang Panjang merupakan pesantren yang sudah mengembangkan program ektrakurikuler, menjadikan pesantren unggul dan kompetitif dengan berbagai inovasi yang mempertimbangkan keunggulan-keunggulan yang telah dimiliki, Keunggulan yang berpotensi untuk dikembangkan bukan hanya terbatas pada demensi akademik. Tetapi, berbagai potensi non akademis juga berpeluang untuk menuju pesantren unggulan, seperti yang telah di sampaikan Waka kesiswaan program yang telah dijalankan adalah tahfizd, pramuka, seni beladiri, drum band, kaligrafi dan muhadoroh.

Pondok Pesantren Thawalib Gunung Padang Panjang, pengelolaan kegiatan ekstrakurikuler yang dilaksanakan di Pondok Pesantren Thawalib Gunung Padang Panjang terlaksana dengan baik, dikarnakan tata kelola atau manajemen kegiatannya sangat tertata dengan baik, sehingga kegiatan dapat berjalan dengan terus menerus dan sudah menjadi kebiasan setiap harinya. Misalnya dalam hal penetapan jadwal kegiatan ekteakurikuler dan implementasi kegiatan ektakurikuler.

Pondok Pesantren Thawalib Gunung Padang Panjang bukan hanya memperhatikan kognitif anak tetapi juga memperhatikan bakat yang terpendam dari santri-santrinya. Pondok Pesantren Thawalib Gunung Padang Panjang sebagai lokasi penelitian didasari dengan berbagai macam pertimbangan, Pondok Pesantren Thawalib Gunung Padang Panjang adalah salah satu lembaga pendidikan Islam yang ada di Padang Panjang yang mulai mengkaji dan menerapkan secara optimal terkait pengembangan mutu pendidikan Islam melalui pengembangan program ektrakurikuler.

Prestasi yang diraih oleh Pondok Pesantren Thawalib Gunung Padang Panjang selama tahun pembelajaran 20162017 sebagai berikut: Juara II Badminton se-Kota Padang Panjang, Juara I Stand Up Komedi Se-Kota Padang Panjang, Juara I putra pidato bahasa arab Se-Kota Padang Panjang, Juara I Putri pidato bahasa arab Se-Kota Padang Panjang, Juara III Kompetensi Sains Madrasah Se-Kota Padang Panjang Tingkat MTs, Juara II Kompetensi Sains Madrasah Se-Kota Padang Panjang Tingkat MA, Juara I Putri Lomba Kepramukaan di STSI Padang Panjang, Juara II Putra Lomba Kepramukaan di STSI Padang Panjang, Juara I Bidang Cerdas Cermat Lomba Galang Prestasi SMKN 1 Bukittinggi.

Pondok Pesantren Thawalib Gunung Padang Panjang bukan satu-satunya pesantren di Padang Panjang, banyak pesantren-pesantren yang besar dan memiliki sarana dan prasaran yang lengkap, manajemen yang bagus, sumber dana yang memadai seperti: Pesantren Serambi Mekkah, Pesantren Nurul Ikhlas, Pesantren Thawalib Putra, Diniyah Putri dan banyak lagi, tetapi tidak semua pesantren yang mewajibkan santri-santrinya untuk mengikuti kegiatan ektrakurikuler. 
Manajemen yang pertama, mewajibkan seluruh santri-santrinya untuk mengikuti setiap kegitan ektrakurikuler seperti, latihan kepramukaan, latihan beladiri, dan latihan muhadoroh pada hari yang telah ditentukan. Kedua, keterbatasan sarana dan prasarana tidak menjadi penghalang bagi pesantren untuk tetap konsekwen dalam menjalankan dan melaksanakan kegiatan-kegiatan ektrakurikuler di pesantren Thawalib Gunung Padang Panjang. Ketiga, keterbatasan sumber dana yang ada tidak menjadi penghalang untuk meningkatkan dan mengembangkan kegiatan ektrakurikuler sehingga dapat mengadakan kemah akbar yang melibatkan seluruh santri dan sudah dua tahun menjadi tuan rumah kejuaraan seni beladiri tapak suci pesantren se-Sumbar.

Berdasarkan beberapa penjelasan terkait latar belakang masalah tersebut di atas, maka menjadikan hal yang sangat menarik bagi peneliti untuk melakukan penelitian judul: "Manajemen Pimpinan Pondok Pesantren dalam Mengembangkan Kegiatan Ektrakurikuler pada Pesantren Thawalib Gunung Padang Panjang".

\section{KAJIAN PUSTAKA}

\section{Manajemen}

Istilah manajemen yang kita kenal secara etimologi berasal dari bahasa inggris, yaitu dari kata kerja "to manage" yang sinonimnya antara lain "to hand" berarti mengurus, "to control memeriksa, "to guide" memimpin. Jadi, bila dilihat dari asal katanya manajemen dapat diartikan sebagai: mengurus, mengatur, melaksanakan dan mengelola. Echlos dan Shadili (1990:
372). Sementara di Indonesia dikenal dengan kata manajemen/managemen yang diterjemahkan ke dalam berbagai istilah seperti kepemimpinan, tata cara memimpin, pengaturan, pengelolaan, pengendalian, pengurusan, pembinaan, penguasaan dan lain sebagainya. (Silalahi 1989: 135).

Dalam proses manajemen pendidikan terlibat fungsi-fungsi pokok yang ditampilkan oleh seorang manajer atau pimpinan, karena fungsi-fungsi tersebut sangat berguna bagi pimpinan di dalam menentukan berhasil atau tidaknya sebuah lembaga.

Para ahli mempunyai perbedaan menurut jumlah dan istilah yang digunakan dalam menetapkan fungsi-fungsi manajemen tersebut, antara lain adalah (Terry dan Roe h. 10) dalam bukunya "Dasar-dasar Manajemen", fungsi manajemen itu adalah:

a) Planning (perencanaan)

b) Organizing (pengorganisasian)

c) Staffing (pengontrolan staf)

d) Motivating (mengarahkan)

e) Controlling (pengawasan)

Prinsip manajemen pada dasarnya dirancang untuk suatu pernyataan dan ketentuan yang bersifat fundamental yang menjadi problem dalam mengambil tindakan-tindakan untuk menghadapi masalah tertentu. Prinsip manajemen sangat perlu diperhatikan dalam kegiatan sebuah lembaga, apalagi lembaga pendidikan. Hendri Payol mengemukakan prinsip manajemen berdasarkan pengalamannya, sebagai berikut: (a) Pembagian kerja (division of work), (b) Otoritas dan tanggung jawab (authority and responsibility), (c) Kesatuan pemerintah (unity command), 
(d) Kesatuan arah (unity of direction) (e) Mendahulukan kepentingan umum dari pada pribadi (subordination of individual to general interest), (f) Penghargaan/ balas jasa (remuneration), (g) Sentralisasi (centralization), (h) Rantai bertangga (scolar chan), (i) Keteraturan (order), (j) Keadilan (equity), (k) Stabilitas pelaksanaan pekerjaan (stability of tenure), (l) Inisiatif (initiative), (m) Jiwa korp (esprit de corp) (Winardi, 2000: 175).

Pimpinan harus mampu membina personil atau bawahan untuk membentuk kelompok kerja dan membinanya malalui sistem dan komunikasi. Dengan adanya sistem komunikatif yang baik akan mewujudkan kelompok kerja demi tercapainya hasil yang baik.

\section{Pimpinan Pondok Pesantren}

Pimpinan Pesantren terdiri dari dua kata, yakni kepala dan madrasah. Pemimpin dalam suatu organisasi, instansi atau lembaga (Suharso dan Ana Retnoningsih, 2005: 236). Sedangkan pesantren adalah pesantren atau perguruan biasanya yang berdasarkan agama Islam. (Suharso dan Ana Retnoningsih, 2005: 302).

Menurut Wahjosumidjo (2013: 83), secara sederhana Pimpinan Pesantren merupakan seseorang yang diberi tugas oleh bawahannya untuk memimpin suatu madrasah di mana di dalam madrasah diselenggarakan proses belajar mengajar. Pimpinan Pesantren merupakan personal pesantren yang bertanggung jawab terhadap kegiatan-kegiatan pesantren (Daryanto, 2011: 80). Oleh karena itu seorang Pimpinan Pesantren dituntut memiliki kemampuan untuk mempengaruhi, mengarahkan dan mengerahkan setiap sumber daya yang ada untuk mencapai tujuan organisasi.

Jadi kepemimpinan Pimpinan Pesantren adalah pimpinan pesantren perlu memposisikan diri sebagai seseorang yang mempunyai pengaruh dan memberikan motivasi kepada seluruh stakeholder yg ada di pesantren tersebut untuk dapat bekerja dengan baik sejalan dengan visi, misi, dan tujuan yang akan dicapai oleh pesantren tersebut.

Setiap Pimpinan Pesantren/madrasah mempunyai karakter dan gaya kepemimpinan yang berbeda-beda. Sebagai seorang pemimpin hendaknya mempunyai gaya kepemimpinan yang dapat diterima seluruh pihak. Dalam hal ini gaya kepemimpinan demokratis merupakan gaya kepemimpinan yang harus digunakan Pimpinan Pesantren/madrasah sebagai seorang pemimpin.

Anoraga dalam Hamdan Dimyati (2014: 76) mengemukakan bahwa pemimpin mempunyai tugas untuk memimpin dan mengendalikan hal-hal detail dan spesifik, juga mengendalikan hubungan internal dalam kelompoknya, karena pada dasarnya dalam suatu kelompok selalu terjadi interaksi. Pemimpin mempunyai tugas untuk menjadi pengamat dan pengendali kelancaran hubunganhubungan yang terjadi.

Tugas dan tanggung jawab kepemimpinan pimpinan pesantren dirumuskan oleh E. Mulyasa (2012: 58-59) sebagai berikut: a). Memahami misi dan tugas pokoknya, b). Mengetahui jumlah bawahannya, c). Mengetahui nama-nama bawahannya, d). Memahami setiap tugas 
bawahannya, e). Memperhatikan kehadiran bawahannya, g). Memperhatikan peralatan yang dipakai bawahannya, h). Menilai bawahannya, i). Memperhatikan karir bawahannya, j). Memperhatikan kesejahteraan bawahannya, k). Menciptakan suasana kekeluargaan, 1). Memberikan laporan kepada atasannya.

Pimpinan Pesantren harus mampu melaksankan tugas dan tanggung jawabnya sebagai seorang pemimpin di sekolahannya dengan baik. Sehingga tercipta keharmonisan dan tujuan sekolah dapat tercapai.

\section{Pondok Pesantren}

Secara bahasa pondok pesantren terdiri dari dua suku kata, yaitu pondok dan pesantren. Pondok berasal dari kata bahasa Arab yaitu funduq yang berarti hotel atau asrama. Sedangkan pesantren berasal dari kata santri, yang dengan awalan pe di depan dan akhiran an berarti tempat belajar para santri, (Dhofier, 1983: 18)

A.H. Johns (1980: 40) berpendapat bahwa istilah santri berasal dari bahasa Tamil, yang berarti guru mengaji. Adapun menurut C.C Breg berpendapat bahwa istilah santri berasal dari kata shastri yang dalam bahasa India berarti orang yang tahu buku-buku agama Hindu, atau seorang sarjana ahli kitab suci Agama Hindu.

Lebih lanjut baliau mengungkapkan bahwa kata shastri berasal dati kata shastra yang berarti buku-buku suci, buku-buku agama atau buku-buku tentang ilmu pengetahuan (Berg, 1932: 257). Jadi secara singkat pondok pesantren dapat dipahami sebagai lembaga atau tempat belajar santri yang di dalamnya dipelajari ilmu-ilmu agama.
Dalam hal penyelenggaraan sistem pendidikan dan pengajaran di pondok pesantren, paling tidak memiliki tiga bentuk, yaitu : pertama, pondok pesantren berfungsi sebagai lembaga pendidikan dan pengajaran agama Islam, yang pada umumnya pendidikan dan pengajaran tersebut diberikan dengan cara non-klasikal (sistem bandongan dan sorogan), dimana seorang kiai mengajar santri-santri berdasarkan kitab-kitab yang ditulis dalam bahasa Arab oleh ulama-ulama besar sejak abad pertengahan, sedang para santri biasanya tinggal dalam pondok atau asrama dalam pesantren tersebut.

\section{Kegiatan Ekstrakurikuler}

Departemen Pendidikan Nasional Badan Penelitian dan Pengembangan Pendidikan Nasional Pusat Kurikulum (2013: 14) kegiatan ekstrakurikuler merupakan kegiatan penopang bagi program intrakurikuler. "Kegiatan ekstrakurikuler adalah kegiatan pendidikan di luar mata pelajaran dan pelayanan konseling untuk membantu pengembangan peserta didik sesuai dengan kebutuhan, potensi, bakat dan minat mereka melalui kegiatan yang secara khusus diselenggarakan oleh pendidik dan tenaga kependidikan yang berkemampuan dan berwenang di sekolah/madrasah". Menurut Sulistyorini, (2009: 80) kegiatan ekstrakurikuler adalah "kegiatan pendidikan yang dilaksanaanya berada di luar jam pelajaran resmi di kelas atau di luar jam mata pelajaran resmi di kelas", seperti kecakapan verbalistik (paduan suara), kecakapan profesi (mading, potografi), dan ketrampilan fisik (olahraga dan seni). 
Vembriarto (1994: 28) dalam kamus pendidikan disebutkan bahwa "kegiatan ekstrakurikuler adalah kegiatan yang ditentukan oleh sekolah dilakukan di luar jam pelajaran intrakurikuler dan kokurikuler dengan tujuan memperluas pengetahuan, bakat, dan minat". Menurut Suryobroto, (2004 h.58-59) kegiatan ekrakurikuler adalah kegiatan yang mencakup semua kegiatan sekolah yang tidak diatur dalam kurikulum. Sebagian dari kegiatan itu dikordinir dan dilaksanakan oleh organisasi Siswa Intra Sekolah (OSIS)

Jadi kegiatan ekstrakurikuler adalah kegiatan-kegiatan yang terdapat dalam suatu lembaga pendidikan, yang dilaksanakan di luar jam pelajaran sekolah yang tidak diatur dalam kurikulum, tetapi masih ditentukan oleh sekolah dengan tujuan memperluas pengetahuan, bakat dan minat siswa. Kegiatan ini dikoordinir dan dilaksanakan oleh OSIS

\section{METODE PENELITIAN}

Penelitian ini termasuk dalam kategori penelitian lapangan (field research). Peneliti menggunakan pendekatan penelitian kualitatif. Menurut Koentjaraningrat (1989: 253) metode kualitatif dengan pendekatan deskriptif, yaitu penelitian dengan menggambarkan peristiwa atau kejadian yang terjadi di lapangan yang menjadi objek penelitian sebagaimana adanya tanpa bermaksud mengkomparasikan atau menggabungkan. Dalam penelitian ini, yang mana dapat menghasilkan penemuanpenemuan yang tidak dapat dicapai dengan menggunakan prosedur-prosedur statistik atau dengan cara kuantifikasi lainnya.
Melalui penelitian kualitatif peneliti dapat mengenali subjek dan merasakan apa yang mereka alami dalam kehidupan sehari-hari, khususnya mengenai manajemen pondok pesantren dalam pengembangan ekstakurikuler di Thawalib Gunung Padang Panjang.

Dalam melakukan penelitian ini, penulis menggunakan dua macam instrumen atau alat yang digunakan dalam pengumpulan data yaitu; (1) Intrumen Kunci, yaitu penulis sendiri, (2) Intrumen Pendukung yang dilakukan dengan wawancara dan studi dokumentasi. Dalam melakukan studi dokumentasi peneliti mengklasifikasikan dukumenn ke dalam 2 jenis, yaitu : (1) Soft copy, (2) Hard copy.

Karakteristik sumber data pada penelitian ini adalah dilihat dari keutamaan objek untuk memperoleh informasi yang lebih objektif. Sumber data dibagi kepada dua bagian, yaitu sumber data primer, yaitu Kepala Sekolah pada Pesantren Thawalib Gunung Padang Panjang. Sumber data sekunder adalah sebagai sumber data pendukung yang terkait dengan penelitian ini, yaitu para guru, siswa, karyawan dan masyarakat yang terlibat dalam Manajemen Pondok Pesantren dalam pengembangan ekstakurikuler di Pesantren Thawalib Gunung Padang Panjang.

Dalam mengumpulkan data, penulis menggunakan tiga cara, yakni dengan observasi, wawancara dan dokumentasi. Sebagaimana disebutkan Emzir (2011: 37), tiga cara inilah yang paling umum dan paling sering digunakan dalam penelitian kualitatatif. Teknik pengumpulan data yang digunakan peneliti dalam penelitian ini 
adalah sebagai berikut: (1) Observasi, (2) Wawancara, (3) Studi Dokumentasi.

\section{HASIL DAN PEMBAHASAN}

\section{Hasil Penelitian}

Setiap kegiatan Pimpinan Pesantren di Pesantren Thawalib Gunung Padang Panjang, selalu diawali dari perencaan yang tertuang dalam program kerja yang dibuat oleh pengurus Pimpinan Pesantren bersama pembina dan bimbingan Pimpinan Pesantren. Program kerja tersebut selalu berorentasi pada penerapkan nilai-nilai Islam, dimana sekolah ini berprinsip bahwa dengan menerapkan nilai-nilai Islam, maka prestasi akademik akan mengikuti. Program yang dibuat dibuat diawal semester dengan melihat kepada potensi dan minat peserta didik. Hal ini juga dimaksudkan agar peserta didik merasa betah dan mau menjalankan program yang dibuat bersama.

Pimpinan Pesantren Pesantren Thawalib Gunung Padang Panjang dalam membuat program penerapan nilai-nilai Islam dengan cermat dan bijaksana, maka dilaksanakannya pembentukan pembina atau penaggung jawab kegiatan. Wujud dari pelaksanaan organizing ini adalah tampaknya kesatuan yang utuh, kekompakan, kesetiakawanan dan terciptanya mekanisme yang sehat, sehingga kegiatannya stabil dan mudah mencapai tujuan yang ditetapkan.

Proses ini selalu dilakukan sepanjang hari. Karena diyakini dengan proses yang baik akan menghasilkan apa yang diharapkan untuk membentuk karakter siswa itu. Maka dari itu dalam proses selalu menekankan adanya proses pembiasaan terhadap nilai-nilai yang ditanamkan, sehingga menjadi kepribadian siswa. Seperti apa yang disampaikan oleh Pimpinan Pesantren Thawalib Gunung Padang Panjang bahwa kami tidak mempermasalahkan dimana anak mendapatkan pendidikan, tapi yang terpenting adalah bagaimana proses itu dijalankan.

Peran guru pembina dan guru-guru lain dalam melakukan pengontrolan program-program yang dibuat oleh Pimpinan Pesantren sangat penting sekali. Karena dari pelaksanaan kegiatan tentu akan ditemukan kendala-kendala. Seperti disiplin anak, motivasi menjalankan program kejujuran ini. Semua perlu bimbingan dan arahan dari pembina dan majlis guru. Sehingga dari kerjasama yang baik yang ditunjukkan oleh majlis guru melalui program kegiatan yang ditetapkan oleh Pimpinan Pesantren dapat disinergikan dengan program yang dibuat untuk penerapan nilai-nilai Islam.

Controlling itu penting sebab merupakan jembatan terakhir dalam rantai fungsional kegiatan-kegiatan manajemen. Pengendalian merupakan salah satu cara para manajer untuk mengetahui apakah tujuan-tujuan organisasi itu tercapai atau tidak dan mengapa terpai atau tidak tercapai. Selain itu controlling adalah sebagai konsep pengendalian, pemantau efektifitas dari perencanaan, pengorganisasian, dan kepemimpinan serta pengambilan perbaikan pada saat dibutuhkan. 


\section{Pembahasan}

\section{Perencanaan Pesantren dalam \\ Mengembangkan Ektrakurikuler pada Pesantren Thawalib Gunung Padang Panjang}

Setiap kegiatan Pimpinan Pesantren di Pesantren Thawalib Gunung Padang Panjang, selalu diawali dari perencaan yang tertuang dalam program kerja yang dibuat oleh pengurus Pimpinan Pesantren bersama pembina dan bimbingan Pimpinan Pesantren. Program kerja tersebut selalu berorentasi pada penerapkan nilai-nilai Islam, dimana sekolah ini berprinsip bahwa dengan menerapkan nilai-nilai Islam, maka prestasi akademik akan mengikuti. Program yang dibuat dibuat diawal semester dengan melihat kepada potensi dan minat peserta didik. Hal ini juga dimaksudkan agar peserta didik merasa betah dan mau menjalankan program yang dibuat bersama. (Wawancara Dengan Pimpinan Pesantren Pesantren Thawalib Gunung Padang Panjang, 10 Nopember 2018)

Siagian mengartikan perencanaan sebagai keseluruhan proses permikiran dan penentuan secara matang menyangkut halhal yang akan dikerjakan dimasa datang dalam rangka mencapai tujuan yang telah ditentukan sebelumnya. Y. Dior berpendapat bahwa yang disebut perencanaan ialah suatu proses penyiapan seperangkat keputusan untuk dilaksanakan pada waktu yang akan datang, yang diarahkan untuk mencapai tujuan tertentu. Dari pengertian di atas, dapat disimpulkan bahwa yang disebut Usman (2006: 48), perencanaan ialah kegiatan yang akan dilaksanakan dimasa yang akan datang untuk mencapai tujuan. Dari sini perencanaan mengandung unsur-unsur yaitu:

1) Sejumlah

kegiatan yang ditetapkan sebelumnya,

2) Adanya proses

3) Hasil yang ingin dicapai

4) Menyangkut masa depan dalam waktu tertentu perencanaan tidak dapat dilepaskan dari unsur pelaksanaan dan pengawasan termasuk pemantauan, penilaian, dan pelaporan. Pengawasan dalam perencanaan dapat dilakukan secara preventif dan represif.

Pengawasan preventif merupakan pengawasan yang melekat dengan perencanaanya, sedangkan pengawasan represif merupakan pengawasan fungsional atas pelaksanaan rencana, baik yang dilakukan secara internal maupun secara eksternal oleh aparat pengawasan yang ditugasi. Usman (2006: 49)

Dengan demikian perencanaan pendi dikan adalah keputusan yang diambil untuk melakukan tindakan selamawaktu tertentu (sesuai dengan jangka waktu perencanaan) agar penyelenggaraan sistem pendidikan menjadi lebih efektif dan efisien, serta menghasilkan lulusan yang lebih bermutu, dan relevan dengan kebutuhan pembangunan Fattah, (1996: 50)

Dalam proses perencanaan terhadap program pendidikan yang akan dilaksanakan, khususnya dalam lembaga pendidikan Islam, maka prinsip perencanaan harus mencerminkan terhadap nilai-nilai islami yang bersumberkan pada alqur'an dan al-Hadits. Dalam hal perencanaan ini alqur'an mengajarkan kepada manusia: 


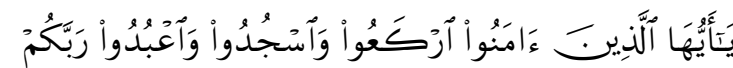

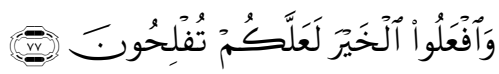

"Hai orang-orang yang beriman, ruku'lah kamu, sujudlah kamu, sembablab Tubanmu dan perbuatlab kebajikan, supaya kamu mendapat kemenangan."

\section{Pengorganisasian Pesantren dalam Mengembangkan Ektrakurikuler pada Pesantren Thawalib Gunung Padang Panjang}

Pimpinan Pesantren Pesantren Thawalib Gunung Padang Panjang dalam membuat program penerapan nilai-nilai Islam dengan cermat dan bijaksana, maka dilaksanakannya pembentukan pembina atau penaggung jawab kegiatan. (Dokumentasi Pesantren Thawalib Gunung Padang Panjang, 08 Desember 2018)

Wujud dari pelaksanaan organizing ini adalah tampaknya kesatuan yang utuh, kekompakan, kesetiakawanan dan terciptanya mekanisme yang sehat, sehingga kegiatannya stabil dan mudah mencapai tujuan yang ditetapkan. Proses organizing yang menekankan pentingnnya tercipta kesatuan dalam segala tindakan, dalam hal ini alqur'an telah menyebutkan betapa pentingnya tindakan kesatuan yang utuh, murni dan bulat dalam suatu organisasi. Firman Allah dalam surat Ali Imran ayat 103:

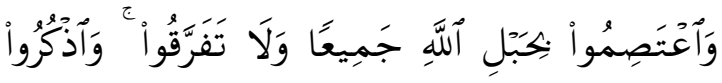

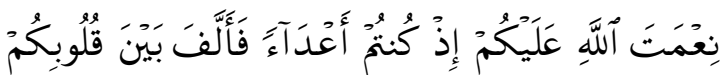

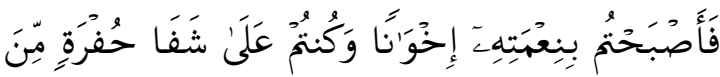

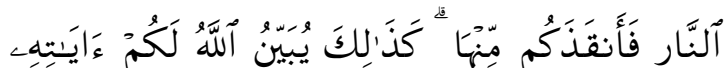

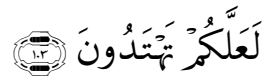

"Dan berpeganglah kamu semuanya kepada tali (agama) Allab, dan janganlab kamu bercerai berai, dan ingatlah akan nikmat Allah kepadamu ketika kamu dabulu (masa Jabiliyah) bermusub-musuban, Maka Allah mempersatukan hatimu, lalu menjadilah kamu Karena nikmat Allah, orang-orang yang bersaudara; dan kamu Telah berada di tepi jurang neraka, lalu Allah menyelamatkan kamu dari padanya. Demikianlah Allab menerangkan ayat-ayat-Nya kepadamu, agar kamu mendapat petunjuk."

\section{Pelaksanaan Pesantren dalam Mengembangkan Ektrakurikuler pada Pesantren Thawalib Gunung Padang Panjang}

Proses ini selalu dilakukan sepanjang hari. Karena diyakini dengan proses yang baik akan menghasilkan apa yang diharapkan untuk membentuk karakter siswa itu. Maka dari itu dalam proses selalu menekankan adanya proses pembiasaan terhadap nilai-nilai yang ditanamkan, sehingga menjadi kepribadian siswa. Seperti apa yang disampaikan oleh Pimpinan Pesantren Thawalib Gunung Padang Panjang bahwa kami tidak mempermasalahkan dimana anak mendapatkan pendidikan, tapi yang terpenting adalah bagaimana proses itu dijalankan. (Wawancara Pimpinan Pesantren Pesantren Thawalib Gunung Padang Panjang, 20 Nopember 2018)

Proses actuating adalah memberikan perintah, petunjuk, pedoman dan nasehat 
serta keterampilan dalam berkomunikasi. Siagian, (1997: 88) Actuating merupakan inti dari manajemen yang menggerakkan untuk mencapai hasil. Sedangkan inti dari actuating adalah leading, harus menentukan prinsip-prinspi efisiensi, komunikasi yang baik dan prinsip menjawab pertanyaan.

Alqur'an dalam hal ini telah memberikan pedoman dasar terhadap proses pembimbingan, pengarahan ataupun memberikan peringatan dalam bentuk actuating ini. Allah berfirman dalam surat al-Kahfi ayat 2:

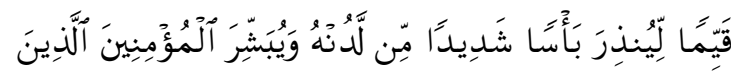

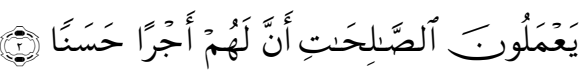

"Sebagai bimbingan yang lurus, untuke memperingatkan siksaan yang sangat pedih dari sisi Allab dan memberi berita gembira kepada orang-orang yang beriman, yang mengerjakan amal saleh, bahwa mereka akan mendapat pembalasan yang baik."

\section{Pengontrolan dan Evaluasi Pesantren dalam Mengembangkan Ektrakurikuler pada Pesantren Thawalib Gunung Padang Panjang}

Peran guru pembina dan guru-guru lain dalam melakukan pengontrolan program-program yang dibuat oleh Pimpinan Pesantren sangat penting sekali. Karena dari pelaksanaan kegiatan tentu akan ditemukan kendala-kendala. Seperti disiplin anak, motivasi menjalankan program kejujuran ini. Semua perlu bimbingan dan arahan dari pembina dan majlis guru. Sehingga dari kerjasama yang baik yang ditunjukkan oleh majlis guru melalui program kegiatan yang ditetapkan oleh Pimpinan Pesantren dapat disinergikan dengan program yang dibuat untuk penerapan nilai-nilai Islam. (Wawancara dengan Waka Kesiswaan Pesantren Thawalib Gunung Padang Panjang, 08 Desember 2018)

Pengawasan merupakan aktivitas yang mengusahakan agar pekerjaan dapat terlaksana sesuai sesuai dengan rencana atau tujuan yang telah ditetapkan. Dengan kata lain pengawasan adalah mengadakan penilaian Sekaligus koreksi sehingga apa yang telah direncanakan dapat terlaksana dengan benar. Fattah, (1996, h. 99)

Controlling itu penting sebab merupakan jembatan terakhir dalam rantai fungsional kegiatan-kegiatan manajemen. Pengendalian merupakan salah satu cara para manajer untuk mengetahui apakah tujuan-tujuan organisasi itu tercapai atau tidak dan mengapa tercapai atau tidak tercapai. Selain itu controlling adalah sebagai konsep pengendalian, pemantau efektifitas dari perencanaan, pengorganisasian, dan kepemimpinan serta pengambilan perbaikan pada saat dibutuhkan. Adapun ayat alqur'an yang berkaitan dengan pengawasan/controllilg adalah sebagaimana firman Allah dalam surat Al-Infithor ayat 10-12

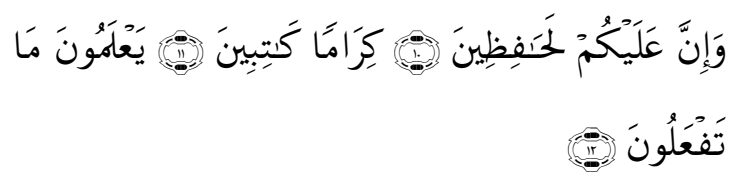

"Padahal Sesunggubnya bagi kamu ada (malaikat-malaikat) yang mengawasi (pekerjaanmu), yang mulia (di sisi Allab) dan mencatat (pekerjaan-pekerjaanmu itu), mereka mengetahui apa yang kamu kerjakan." 


\section{PENUTUP}

\section{Kesimpulan}

Berdasarkan hasil temuan penelitian dapat dikemukakan bahwa manajemen pimpinan pondok pesantren dalam mengembangkan kegiatan ekstrakurikuler pada Pesantren Thawalib Gunung Padang Panjang adalah menerapkan prinsip manajemen pada umunnya yang memenuhi kriteria perencanaan, pengorganisasian, kontrol dan pengawasan serta evaluasi atau yang biasa disebut POAC.

Dalam penerapan menajemen ini Pimpinan Pondok Pesantren Thawalib Gunung menjalani seperti berikut: (1) Perencanaan: merumuskan perencanaan pengelolaan ekstra kurikuler dengan melibatkan seluruh unsur struktural Pesantren dan majelis guru, (2) Pengorganisasian: dengan pengorganisasian dengan menempatkan penanggung jawab kegiatan yang sesuai dengan kebutuhan, serta melibatkan siswa tingkat akhir sebagai mentor sebaya, (3) Pelaksanaan: memberikan perhatian yang sungguh-sungguh dalam pelaksanaan mulai penegakan disiplin baik untuk pengelola maupun peserta, teriintegrasi dengan tujuan pondok serta menjaga singkronisasi dengan pernecanaan yang telah ditetapkan. (4) Evaluasi: melakukan evaluasi secara bertingkat, baik evaluasi peserta maupun evaluasi secara keseluruhan yang bertujuan untuk meningkatkan mutu kegiatan dan pengembangan kegiatan secara berkelanjutan. Keberhasilan program yang direncanakan tidak terlepas dari komitmen dan keseriusan mereka dalam menjalankan kegiatan yang direncanakan. (5) Kontrol dan evaluasi yang terus menerus sebagai prioritas utama. Oleh karena itu seluruh kegiatan yang ada berjalan dengan baik dan maksimal, meskipun minim dukungan saran dan prasarana, tetapi tetap meraih prestasi dalam berbagai kegiatan baik ditingkat kota, Provinsi dan nasional.

\section{Saran}

1. Diharapkan kepada Pimpinan Pondok Pesantren Thawalib Gunung bersamasama warga pesantren agar mempertahankan sistem manajemen yang telah dibangun bersama.

2. Diharapkan kepada guru agar dapat melakukan inovasi lebih baik lagi pada kegiatan estrakurikuler, dengan memanfaatkan lingkungan sebagai sumber belajar serta melaksanakan kegiatan estrakurikuler secara efektif dan efisien.

3. Madrasah atau sekolah lain bisa menjadikan Thawalib Gunung sebagai contoh dalam mengelola kegiatan ekstrakurikuler dengan segala keterbatasan yang ada tetapi bisa tetap eksis dan berprestasi ditingkat kabupaten, kota dan propinsi bahkan sampai pada tingkat nasional.

4. Kesungguhan dan komitmen yang jelas dalam melaksanakan kegiatan disertai control dan pengawasan sebagai prioritas utama merupakan salah satu kunci keberhasilan Thawalib Gunung dalam mengelola kegiatan ekstrakurikulernya adalah teladan yang bisa dilaksanakan pada sekolah lain.

5. Diharapkan pada pemerintah daerah Padang Panjang maupun pemerintah pusat agar memberikan perhatian pada Pondok Pesantren Thawalib Gunung yang sedang berkembang terutama 
peningkatan bantuan fasilitas bagi tercapainya tujuan akativitas ekstrakurikuler sebagai pendukung dalam pembentukan karakter anak didik.

6. Diharapkan akan ada penelitian lanjutan yang dilaksanakan oleh peneilti lain yang membahas tentang menajemen ekstra kurikuler baik di pesantren lainnya maupun di madrasah swasta dan negeri, sebagai pebanding dalam rangka penyempurnaan pelaksanaan menajemen ekstrakurikuler di sekolah/madrasah maupun di pesantren.

\section{KEPUSTAKAAN ACUAN}

Agus S. Suryobroto, 2004. Sarana dan Prasarana Pendidikan Jasmani: Universitas Negeri Yogyakarta: Fakultas Ilmu Keolahragaan.

Ana Retnoningsih dan Suharso 2005, Kamus Besar Bahasa Indonesia, Semarang, Widya Karya.

A.H. Johns, Rom Coastal Settlement to Islamic School and City: Islamization in Sumatra, The Malay Paninsula and Java, “ dalam J. Fox (ed), Indonesia: The Making of a Culture (Camberra : RS.P.S., A.N.U., 1980).

B. Suryosubroto. 2009. Proses Belajar Mengajar di Sekolah. Jakarta: Rineka Cipta

C.C. Berg, "Indonesia," dalam H.A.R. Gibb (ed). Whiter Islam; A Survey of Modern Movement in The Moslem World, (London; 1932).

Daryanto. 2011. Kepala Sekolah sebagai Pemimpin Pembelajaran. Yogyakarta: Gava Media
Dimyati, A. Hamdan. 2014. Model Kepemimpinan dan Sistem Pengambilan Keputusan. Penerbit Pustaka Setia: Bandung.

Dhofier, Zamakhsyari. (1983). Tradisi Pesantren Studi tentang Pandangan Hidup Kyai, LP3S, Jakarta.

E. Mulyasa, Menjadi Kepala Sekolah Professional, (Bandung: Rosda Karya, 2007)

E Mulyasa. 2012. Manajemen dan Kepemimpinan Kepala Sekolah. Jakarta: Bumi Aksara.

Emzir, 2011. Metodologi Penelitian Kualitatif Analisis Data. Jakarta: Raja Grafindo.

Fattah, Nanang, 1996. Landasan Manajemen Pendidikan. Bandung: PT Remaja Rosdakarya.

George R. Terry, 1993. Prinsip-Prinsip Manajemen. Jakarta: Bumi Aksara.

George R. Terry, The Principl of Management, (Illionis: 1973).

Jhon M. Echlos dan Hasan Shadili, 1990. Kamus Inggris Indonesia. Jakarta: Gramedia,.

Permendikbud RI Nomor 81A Tahun 2013 Tentang Implementasi Kurikulum Pedoman Kegiatan Ekstrakurikuler, pada lampiran ke III.

Rahmat Raharjo Syatibi, 2013. Pengembangan \& Inovasi Kurikulum. Yogyakarta: Azzagrafika.

Siagian, H.,1997, Manajemen Suatu Pengantar, Alumni Bandung. 
Sinar Ulberet Silalahi, 1989. Studi Tentang Ilmu Administrasi, Konsep Teori dan Dimensi, Bandung Baru.

Sulistyorini. 2009. Manajemen Pendidikan Islam; Konsep, Strategi, dan Aplikasi. Yogyakarta: Teras.
Vembriarto, St., dkk., 1994. Kamus Pendidikan. Jakarta: Grasindo, 1994.

Wahjosumidjo. 2013. Kepemimpinan Kepala Sekolah . Jakarta: PT Raja Grafindo Persada.

Winardi, 2000. Kepemimpinan dalam Manajemen. Jakarta: Rineka Cipta. 